\title{
Optimum water safety
}

Castellini understands how important it is to keep the water quality inside DUWLs as safe and clean as possible. As a result, the Skema 8 has been expertly designed to incorporate scientifically proven hygiene devices for optimum protection and peace of mind.

Certified by DVGW - the largest gas and water industry certification body in Europe - dental professionals can rest assured that the microbiological water quality inside the Skema 8 is ensured by a bactericidal, fungicidal and micro-bacterial disinfectant that acts against all water-borne contaminants including Legionella.

Castellini also supplies the innovative

A.C.A. spray anti-retraction system as standard on all dynamic instruments to prevent the aspiration of any contaminations during the stopping phase.

With over 80 years' experience in the design and manufacture of dental units, Castellini is dedicated to innovation, style and consistent quality that you can trust.

If you would like to find out how you can minimise the risks of infection and cross contamination from DUWLs, find out more about the Skema 8 from Castellini today.

If you require any further information call 08000933975 and speak to Castellini UK directly for assistance.

\section{A powerful combination in Cologne}

Demonstrating its most exciting innovations in the field of dental implantology, Nobel Biocare invites you to discover its latest products and concepts at IDS 2017 in Cologne this March.

Alongside the presentation of brand new products designed to help you treat even more patients better, the team will be delighted to show you previous solutions that have received fantastic feedback from professionals in the past year. These will include the extraordinary On1 concept, revolutionising the restorative workflow with tissue-level restoration and optimised soft tissue healing, and the Multi-unit Abutment Plus, simplifying the chairside denture conversion process.

What's more, Nobel Biocare will be offering more details on its partnership with KaVo Kerr. This powerful combination of leading dental innovators is set to make the link between technology and excellent patient care stronger than ever.

To find out more about the new partnership and to discover the brand new and exciting products being launched, don't miss Nobel Biocare at IDS 2017, Hall 10.1, stands $\mathrm{H} 020$ and $\mathrm{J} 020$.

For more information, contact Nobel Biocare on 02087563300 or visit www. nobelbiocare.com.

\section{Time saving impressions without retaking}

\section{GC's NEW Aadva IOS (Intra Oral Scanner) revolutionises digital impression taking technology because it enables time saving impression taking without retakes. The} software visually advises the operator if the image is incomplete, thus preventing the need for remakes. In conjunction with the Aadva Lab Scan it ensures a perfect fit for all final restorations and provides real-time communication between the surgery and laboratory. There is also a time and cost saving element on impression materials and postage. Finally, the Aadva IOS ensures greater patient satisfaction via greater treatment comfort and faster results.

Aadva IOS features user-friendly technology that makes it much less technique sensitive. It also removes impression related issues relating to tears, bubbles and voids; tray-to-tooth contact; impression material and tray separation; dimensional stability; limited working time; inaccurate pouring during model manufacture, model breakage during shipment; and patient discomfort.

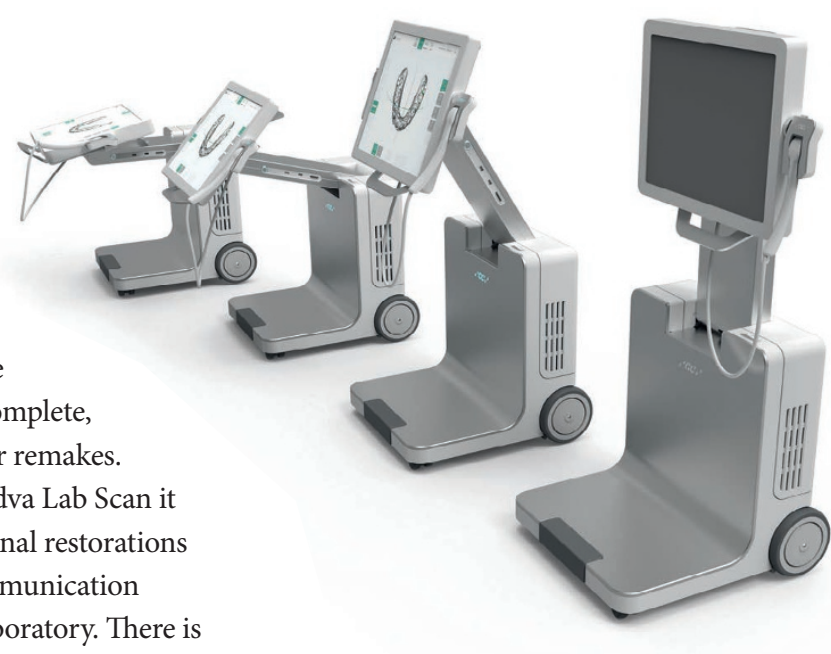

Weighing just $70 \mathrm{~g}$ the Aadva IOS is the lightest handpiece on the market. Facilitating powder-free scanning, it offers an easy technique which creates less anxiety for the practice and less chair time.

The Aadva IOS requires no calibration and its offline file calculation facility enables fast processing times.

For further information contact GC UK Ltd on 01908 218999, email info@gcukltd. co.uk or visit www.gceurope.com.

\section{New CPD courses this spring}

Dedicated to supporting and assisting with training courses, Nuview is pleased to announce two new upcoming courses in association with Seminars@ thirtyeight - a leading London centre for continuing professional development.

The events are:

- Anterior and Anterior ADVANCED Hands-On Composite Course on Friday 17 and Saturday 18 March 2017

- Hands-On Composite Course Double Bill: Posterior and Anterior Direct Resin Artistry on Friday 21 and Saturday 22 April 2017.

Dr Jason Smithson will present the courses, both of which are worth 16 hours of verifiable CPD.

For more information about the anticipated learning outcomes or to book a place on one or both of the courses, get in touch - but hurry, there are only limited places available.

For more information call Nuview on 01453 872266, email info@nuview-ltd. com or visit www.nuview.co. 